\title{
Çalışanların Performansı, Yaratıcılığı ve Öğrenme Davranışı Üzerinde Kontrol Olgusunun Etkisi: Havacılık Sanayinde Araştırma
}

\author{
Güzin KIYIK KICIR *
}

Çalışanların Performansı, Yaratıcılığı ve Öğrenme Davranışı Üzerinde Kontrol Olgusunun Etkisi: Havacılık Sanayinde Araştırma

Özet

Öğrenme, yaratıcılık ve performans iş yaşamında çalışanların başarııında öne çıkan kavramlar arasındadır. Etkisi incelenen kontrol olgusuysa planlarla gerçeklerin karşılaştıııması ve gerektiğinde sapmaların düzeltilmesiyle ilgilidir. Bu makalenin amacı örgütlerde yürütülen kontrol faaliyetlerinin çalışanların yaratııılıkları, öğrenme davranışı ve performansları üzerindeki etkisini incelemektir. Bu amaçla kontrol; yönetimsel olarak resmi ve gayri resmi kontrol başlığında iki alt boyut ve bunların alt bileşenleriyle ele alınmıştır. Uygulama alanı olarak seçilen havaclık sanayi üzerinde, belirlenen faktörler arasındaki ilişkiler yapısal eşitlik modeliyle analiz edilmiştir. Sonuç olarak; kişisel kontrol haricinde hiçbir kontrol bileşeninin yaratıcılıküzerinde etkili olmadığı ancak sosyal kontrol dışındaki tüm kontrol türlerinin öğrenme üzerinde etkiye sahip olduğu ortaya çıkmıştır. Bir başka bulgu da kontrol türlerinin aracı olmadan doğrudan performans ile arasında anlamlı bir ilişki bulunmamasıdır.

Anahtar Kelimeler: Kontrol, Yaratıclık, Öğrenme, Performans, Yapısal Eşitlik Modeli
The Control Effect on Performance, Creativity and Learning Behavior of Employees: A Study on the Aviation Industry

\section{Abstract}

Learning, creativity and performance are among the outstanding concepts in the success of employees in business life. The concept of control the effect of which is examined is something related to comparison of plans and facts and the correction of deviations when needed. The aim of this article is to examine the impact of control activities carried out by organizations on the creativity, learning behavior and performance of employees. For this purpose; Control is handled in terms of two dimensions (official and unofficial title) and their subcomponents as administrative. On the aviation industry selected as application area, the relationships among the identified factors have analyzed via structural equation modeling. Consequently; no control components have an impact on creativity except for personal control. Whereas, that all control types have an impact on learning have appeared with the exception of social control. In other notable finding; without mediating variable, it is that there isn't a significant correlation kinds of control between performance directly.

Key Words: Control, Creativy, Learning, Performance, Structural Equity Model

\section{Giriş}

İçinde bulunduğumuz çağ değişim ve belirsizlikle şekillenen bir dönem olma özelliğindedir. Gerek ülke yönetimlerinde, gerekse örgütler açısından bu şartları dikkate almadan hareket etmek pek çok riski beraberinde getirir. Değişimi hızlı ve pozitif kılabilecek ayrıca belirsizliklere karşı esnek ve

* Güzin KIYIK KICIR, Yrd.Doç.Dr., Anadolu Üniversitesi, Uzaktan Öğretim Bölümü, gkiyik@anadolu.edu.tr 


\section{Güzin KIYIK KICIR}

çevik bir cevap verebilme yeterliliğine sahip örgütler için pek çok avantaj mevcuttur. Çevre koşullarını göz ardı etmeden açık sistem özelliğini koruyarak başarılı olma hedefine sahip örgütler sürekli yükselen bir seyir izleyebilme yetisine sahip olurlar (Gürkan, 2007). Çevresel değişimlere uyum sağlamada en önemli faktörlerden biri örgütlerin öğrenme becerilerini bireysel seviyeden örgüt seviyesine yayacak yaklaşımlar geliştirmeleridir (Atak ve Atik, 2007). Bu bağlamda yenilikçi yönetim anlayışları ve yaratıcılık da esnek olmaya gayret gösteren kurum yapılarını destekleyici bir unsur olarak karşımıza çıkmaktadır. Yaratıcılığa gereken değeri göstererek kendilerini sürekli yenileyebilen işletmeler, küreselleşmenin artırdığı belirsiz çevre koşullarından daha az etkilenmekte ve yoğun rekabet ortamında ayakta kalabilmektedir (Tierney et al., 1999; Wong and Pang, 2003a). Argon ve Eren (2004) tarafından iş görenin görevini gerçekleştirmek için yaptığı her işlem ve eylemi ifade eden performans davranışı işletmeleri etkileyen bir diğer kavramdır. Örgütlerin kurumsal hedeflerine ulaşabilmeleri ve içinde bulundukları sektörde rekabet gücü kazanabilmeleri için, yaptıkları işte yüksek performans gösteren çalışanlara ihtiyaçları vardır (Yelboğa, 2006). Çevresel şartlara uyum sağlama ve işletme başarısı konusunda önemli olan bu kavramlar uygulandıkları işletme atmosferi açısından uygun koşullarda daha aktif rol oynayabilir. Öğrenme, yaratıcılık ve performans kavramları destekleyici ve sınıllandırıcı örgüt yapılarında farklılaşabilmektedir. Araştırma kapsamında bu kavramlarla ilişkisi sorgulanan boyut ise kontrol kavramıdır. Kalitenin sorgulandığı, müşteri memnuniyetinin öncelikli görüldüğü, hata paylarının sıfıra yaklaştırıımak için çalışmaların yürütüldügü günümüz iş dünyasında kontrol önemi yadsınamayan bir olgudur. Yönetimin geri bildirim sağlama özelliğindeki son fonksiyonu olan kontrol, bir işletmenin hedeflerine sağlıklı bir biçimde ulaşmasını sağlayacak önlemleri ifade eder (Elitaş, 2004:34). Kontrolün asıl amacı, hataları ve zayıf noktaları ortaya çıkarmak, düzeltici önlemler alarak bunların tekrarını engellemektir (Doyrangöl, 2002:47). Kontrol fonksiyonu işletmeler için önemli olmakla birlikte, doğası gereği sınırlandırıcı ve standartları olan bir örgütsel yapıyı da ortaya çıkarmaktadır. Bu yapının işletme başarısı için gerekli görülen öğrenme, yaratıcılık ve performans kavramları üzerindeki etkisi araştırmanın çıkış noktasını oluşturmaktadır. Kontrol ile diğer değişkenler arasında ilişki olup olmadığı, varsa bu etkinin pozitif mi, yoksa negatif mi olduğu soruları geliştirilen hipotezler ve araştırma modeli aracılığıyla sorgulanmaktadır. Bu bağlamda iş ve süreçlerle ilgili uygulanan kontrol faaliyetleri bağımsız değişken olurken, çalışanların yeni fikirleri yaratma becerileri, işletme içerisindeki performansları ve öğrenme davranışları bağımlı değişken konumundadır. Sonuç olarak ortaya çıkan bulgular ise; kontrol faaliyetlerinin, değişkenler açısından nasıl uygulanabileceğine dair öneriler düzeyinde yorumlanmaktadır.

\section{Kontrol}

Küreselleşme, teknolojik gelişmeler ve işletmelerin faaliyetleriyle ilgili işlem sayısının çokluğu ve karmaşıklı̆ı gibi nedenlerden dolayı işletme yönetimi; işletme faaliyetlerinde etkinliğin artırılması, hile ve hataların önüne geçilmesi ve varlıkların korunması gibi konularda kontrol sistemlerine ihtiyaç duymaktadır. Gerek üretim, gerekse hizmet sanayinde faaliyet gösteren örgütlerde kalite standart- 
larının oluşması, yürütülen faaliyetlere ilişkin hataların azaltılması, sorunlu ürün ve hizmetlerin ortaya çıkaracağı ek maliyetlerden kurtulma noktasında kontrol fonksiyonu önemi ve geçerliliğini koruyan bir kavramdır.

Yönetim biliminin kurucularından Henry Fayol kontrolü "Her şeyin verilen emirlere ve var olan kurallara uygun şekilde olmasını gözetlemek olarak tanımlamıştır. Amacını ise; örgütün işleyişindeki hata ve eksiklikleri ortaya çıkararak tamir etmek ve bir daha yapılmasının önüne geçmek olarak ifade etmiştir (Fayol, 1917:153). Kontrol ayrıca, örgütün esas amaçlarının ve bu amaçların elde edilmesi için yapılan planların gerçekleşmesinde görev alan astların, verimlilik durumlarının ve çalışmalarının ölçülmesi ve gerektiğinde düzeltilmesi için yapılan işlemler olarak tanımlanmaktadır (Stoner, 1982:595). Örgütlerde kontrol kavramı, hataları görme, düzeltme, maliyetleri azaltma ve bir adım öncesinde durum öngörebilmek adına gereklidir. Ayrıca fonksiyonel performans ve organizasyonel gelişme açısından da önem arz etmektedir (Sisaye, 2005, ss 51-52).

Örgütsel açıdan kontrol fonksiyonunu üç düzeyde incelemek mümkündür. Bunlar; stratejik planlama ve kontrol, yönetim kontrolü ve eylemsel kontroldür. Bu çalışmanın ana eksenini oluşturan yönetim kontrolü, çalışanların örgüt hedefleri doğrultusunda çalışmaya özendirilmesi anlamına gelmektedir. Yönetim kontrolü ayrıca bu hedeflerin başarılması sırasında ortaya çıkan her türlü yanlış, hatalı ve zararlı faaliyetin saptanması, düzeltilmesi ve tekrarının önlenmesini de içerir (Gürsoy, 1999, s.585). Literatüre bakıldığında yönetim kontrol sistemleri; faaliyet ve davranış kontrolleri, kişisel ve sosyal kontroller, sonuç-çıktı kontrolleri olmak üzere üç gruba ayrılmaktadır (Yücel ve Eren 2010). Jaworski (1988) ise; bu grupları araştırmaları doğrultusunda resmi ve gayri resmi kontroller olmak üzere iki başılıkta ve onların alt boyutlarıyla sınıflandırmayı tercih etmiştir. Kontrol mekanizmaları düzeyinde ele alınmak istenen tüm boyutları içermesi, işletme içerisinde resmi ve resmi olmayan iletişim ağlarını dikkate alması ve kontrol olgusuna üretim faaliyetleri açısından hem süreç, hem de çıktı düzeyinde yer vermesi nedeniyle kontrol boyutu araştırma kapsamında bu sınıflandırmaya göre değerlendirilmiştir.

\subsection{Resmi Kontrol}

Gerek iş süreçlerinde, gerekse üretilen ürün ve hizmetler konusunda denetlenecek her konunun üst düzey yöneticiler tarafından tasarlandığı önceden kural ve standartların getirildiği kontrolleri kapsamaktadır. Çalışanların ya da grupların belirli hedefleri destekleyecek şekilde davranma olasılı̆̆ını etkileyen, yazılı ve yönetim tarafından oluşturulup yürütülen mekanizmalardır (Jaworski, 1988, s.26).

Resmi kontrollerin alt boyutları süreç ve çıktı kontrolüdür. Süreç kontrolü; üretilen ürün ve hizmet süreci içerisinde önceden tanımlanan kontrol işlemlerinin bütünüdür. Jaworski'ye göre (1988) işletmenin arzu edilen sonuçlara ulaşmak için kullanılan araçları etkilemek istediğinde başvurduğu yol olarak görülmektedir. Çıktı kontrolü ise; faaliyetler yerine sonuca odaklanmayı tercih eden ürün ya da hizmet üzerinde yönetim tarafından önceden belirlenerek, denetlenen tüm konu başlıklarını kapsar. Performans standartlarının belirlendiği, gözlendiği ve sonuçların değerlendirildiği ortamlarda uygulanır. 


\section{Güzin KIYIK KICIR}

\subsection{Gayri Resmi Kontrol}

Örgütlerde yer alan birimlerdeki birey ya da grupların davranışlarını etkileyen, yazılı olmayan, genellikle çalışanlar tarafından başlatılan mekanizmalardır (Jaworski, 1988, s.26). Resmi kontroller kadar hazırlıklı ve hedef odaklı olmasa da gayri resmi kontrollerde çeşitli amaçlar için destekleyici olabilir.

Gayri resmi kontrollerin bu araştırma kapsamında ele alınacak iki alt boyutu kişisel ve sosyal kontroldür. Kişisel kontrol; bireyin kendi kendini denetlediği bir çeşit otokontrol durumudur. Bir başka ifadeyle çalışanların bireysel hedef koyarak eylemlerini kendilerinin düzenlemesidir (Jaworski 1988, s.26; Merchant, 1988, s.24). Bu noktada hedeflerin gerçekleşip gerçekleşmediğini çalışan kendisi gözlemlemekte ve sonuç olarak davranışlarını buna göre uyarlamaktadır. Hammar ve Vardi'de (1981) benzer şekilde kişilerin kontrol odaklarının çalışma hayatlarında sergiledikleri davranışları ve başarıyı etki ettiğini savunmaktadır. Sosyal kontrol ise; örgüt içerisinde grupların kendi aralarındaki etkileşimleriyle ortaya çıkan kontrol türüdür. İş birimi belirli standartlar (normlar) ortaya koyar, buna uyumu gözlemler ve sosyal sapmalar ortaya çıktığında kişiler arası etkileşim biçimleri ve sosyal bakış açıları aracılığıyla faaliyete geçer. Burada kontrolün kaynağı, değerlerin içselleştirilmesi ve bazı ortak hedeflere yönelik karşılıklı bağ|ıııtır. Performans normları bir kez belirlenip, sapmalar ortaya çıktığında grup bu davranışı mizah, muziplik ya da ima gibi kontrol biçimleriyle değiştirmeye çalışmaktadır (Yücel ve Eren, 2010, s.100).

\section{3. Öğrenme}

Yeni ekonomi, bilgi ve inovasyon üzerine kurulu bir ekonomi olduğundan dolayı, günümüzde öğrenme günlük hayatın vazgeçilmez bir parçası olmuş ve bu gelişmeler, bireylere ve örgütlere etkin olabilmeleri için öğrenme sorumluluğu ve zorunluluğu yüklemiştir (Tapscott,1998: 182-183; Khandekar and Sharma, 2006: 683). Bu zorunluluk, örgütleri hayatta kalabilmek için değişmeye ve yeni yollar öğrenmeye yönlendirmiştir. Bu anlamda örgütlerin öğrenme ihtiyacı, çevredeki sürekli ve hızlı değişimlerden kaynaklanmaktadır (Öneren, 2008).

Öğrenme iş ortamında ve dışında bireyin yaşadığı tecrübeler ve bunun grup çalışmalarıyla örgüt düzeyine yayılması sonucunda oluşmaktadır (Özgen, Kılıç, Karademir, 2004). Soyut ve dinamik bir olgudur. Çevresel değişimlerin izlenmesi kadar içsel ilişkilerin yönlendirilmesi sürecini de kapsamaktadır (Schein, 2004: 395). Birey, grup ve örgüt gibi değişik düzeylerdeki kabiliyet, bilgi, kavram veya davranışları bir bütün haline getirerek problem çözmeyi, tutum ve düşünceleri bütünleştirmeyi sağlar (Öneren, 2008). Her ne şekilde adlandııısın veya tanımlansın, öğrenme sonucu oluşan bilgi, örgütler için rakipleri pasifize etme ve onlara göre bir adım önde olma amaçlarını gerçekleştirebilecek stratejik bir girdidir (Atak ve Atik, 2007). Bu girdinin doğru ve etkin kullanılması örgütlere faaliyetlerini gerçekleştirme ve rekabet avantajı elde etme anlamında pek çok üstünlük sağlamaktadır. 


\section{Yaratıcilık}

Literatürde yaratıclık; bir faaliyet, süreç ya da program olarak ele alınmaktadır (Baharadwaj and Menon, 2000, 425). Shalley ve arkadaşları $(2000,215)$ kavramı, bireyler veya gruplar tarafından yeni ve yararlı fikirlerin, süreçlerin ve prosedürlerin üretimi, kavramsallaştırılması ve geliştirilmesi süreci olarak tanımlar. Yaratıcılığın en kabul gören tanımlarından birisi de, yaratıcılığın her alanda yeni ve yararlı fikirlerin üretilmesi (Amabile vd., 1996, s.1154) olarak değerlendirilmesidir. Yaratıcılık yeni bir şeyler üretme yeteneği olarak tanımlanabileceği gibi, bizi yeni, yararlı ve anlaşılabilir sonuçlar üretmeye yönelten bir süreç olarak da tanımlanabilir (Kao, 1989, s.14).

İçinde bulunduğumuz bilgi çağında, teknoloji yoğun işletmeler için önemli olan yaratıcılık, özellikle yeni ürün ve hizmeti sürekli şekilde üreterek rekabet etmesi gereken şirketler için ayrı bir öneme sahiptir (Wu vd., 2008, 588). İşletmeler küçük iyileştirmeler yerine iş dünyasında fark yaratacak yenilikçi ve yaratıı fikirler oluşturarak rakiplerinin arkasında kalmaktan kurtulup, varlıklarını koruyabilir (Yıldırım, 2007, 110).

Yaratıcılık, Guilford (1950) tarafından yapılan araştırmalarla bir çalışma alanı haline gelmiş, 1990 yılında yapılan araştırmalarla önemli gelişmeler göstermiştir. Bu araştırmalarda yaratıcılık ile motivasyon, cinsiyet ve eğitim durumu arasındaki ilişki ve ayrıca yaratıcılığın sonuçları belirlenmeye çalışıımıştır (Wong and Ladkin, 2008). Araştırmalar sınırlandırıcı unsurlar yerine yöneticinin çalışanlarını teşvik etmesinin ve bağlı olduğu yöneticiler ile çalışanları arasında açık bir etkileşimin sağlanmasının, yaratıcılık ve yenilikçiliği arttırdığını göstermektedir (Shalley, Gilson ve Blum, 2000: 216).

\section{Performans}

Organizasyonlarda çalışanların performanslarının sistematik ve biçimsel olarak değerlendirilmesinin ilk örnekleri 1900'lü yılların başlarında A.B.D.'de kamu hizmeti veren kurumlarda görülmektedir. Daha sonraları F. Taylor'un iş ölçümü uygulamaları aracılığı ile çalışanların verimliliklerinin ölçülmesinin sonucu, performans değerlendirme kavramı organizasyonlarda bilimsel olarak kullanımaya başlanmıştır (Uyargil, 1994).

Performans; görev çerçevesinde önceden belirlenen ölçütleri karşılayacak biçimde, görevin yerine getirilmesi ve amacın gerçekleştirilmesi yönünde ortaya konan mal, hizmet ya da düşüncedir (Pugh, 1991, s.7-8). Bir diğer kaynakta, bir kişinin sahip olduğu potansiyel veya reel bilgi-maharet ve kabiliyetlerini hedeflerine veya beklentilerine ulaşabilmek için ne ölçüde kullanabildiğini tanımlayan bir kavram olarak kullanılmıştır (Şehitoğlu ve Zehir, 2010).

Örgütsel davranış açısından performans, işgörenin örgütsel amaçları gerçekleştirmek için görevi ile ilgili eylemlerinin ve işlemlerinin sonunda elde ettiği üründür. Bu ürün mal, hizmet, düşünce türünden olabilir (Başaran,1991, s.179). Örgütlerde arzu edilen düzeyde bir etkinliğin sağlanabilmesi için performansın yönetilmesi zorunludur (Tutar ve Altınöz, 2010). Performans yönetimi, örgütün başta insan kaynakları olmak üzere finansal ve fiziksel kaynaklarının arzu edilen verimlilik ve etkinlik düzeyine ulaşmasını ve bunun sürdürülmesini sağlama sürecidir (Bolton, 1997: 183). Performans yönetimiyle çalışanların bilgi, beceri, yetenek ve genel anlamda meslekî yetkinliği artııımaya çalışılır. 


\section{Güzin KIYIK KICIR}

Böylece örgütsel hedefler, plân ve politikalar çerçevesinde kurumsal performans iyileştirilebilir (Tutar ve Altınöz, 2010).

\section{Araştırma Yöntemi}

Bu çalışmada kontrol olgusunun son derece önemli olduğu bilinen ve hataları minimize eden yönetim sistemleriyle çalışan havacılık sanayi, uygulama alanı olarak seçilmiştir. Veriler hazırlanan anketler aracılığıyla toplanmış ve yapısal eşitlik modeliyle analiz edilmiştir. Yapısal eşitlik modeli; açık ve gizli değişkenler arasındaki nedensel ve korelasyonel ilişkilerin bir arada bulunduğu modellerin test edilmesi için kullanılan kapsamlı bir istatistik yaklaşımdır (Hoyle and Panter, 1995: s.158-177). Bu yöntem aracılığıyla kontrol ile yaratıcılık, öğrenme ve performans arasındaki ilişkiler test edilirken aynı zamanda araştırma hipotezlerine de yanıt aranmıştır. Bu çalışma kapsamında irdelenen araştırma hipotezleri şunlardır:

H1: Sosyal kontrol, çalışanların öğrenme davranışını pozitif yönde etkiler.

H2: Sosyal kontrol, çalışanların yaratıcılığını pozitif yönde etkiler.

H3: Sosyal kontrol, çalışanların performansını pozitif yönde etkiler.

H4: Kişisel kontrol, çalışanların öğrenme davranışını pozitif yönde etkiler.

H5: Kişisel kontrol, çalışanların yaratıcılığını pozitif yönde etkiler.

H6: Kişisel kontrol, çalışanların performansını pozitif yönde etkiler.

H7: Süreç kontrolü, çalışanların öğrenme davranışını negatif yönde etkiler.

H8: Süreç kontrolü, çalısanların yaratıcılığını negatif yönde etkiler.

H9: Süreç kontrolü, çalışanların performansını pozitif yönde etkiler.

H10: Çıktı kontrolü, çalışanların öğrenme davranışını negatif yönde etkiler.

H11: Çıktı kontrolü, çalışanların yaratıcılığını negatif yönde etkiler.

H12: Çıktı kontrolü, çalışanların performansını pozitif yönde etkiler.

H13: Sosyal kontrol, çalışanların performansını öğrenme davranışı üzerinden etkiler.

H14: Sosyal kontrol, çalışanların performansını yaratıcılık üzerinden etkiler.

H15: Kişisel kontrol, çalışanların performansını öğrenme davranışı üzerinden etkiler.

H16: Kişisel kontrol, çalışanların performansını yaratıcılık üzerinden etkiler.

H17: Süreç kontrolü, çalışanların performansını öğrenme davranışı üzerinden etkiler.

H18: Süreç kontrolü, çalışanların performansını yaratıcılık üzerinden etkiler. 
H19: Çıktı kontrolü, çalışanların performansını öğrenme davranışı üzerinden etkiler.

H20: Çıktı kontrolü, çalışanların performansını yaratıcılık üzerinden etkiler.

Çalışmada ölçüm aracı olarak uygulanan anketlerdeki süreç, çıktı, kişisel ve sosyal kontrol bileşenleri, Jaworski ve McInnes (1989) tarafından geliştirilen, güvenilirliği geçerliliği test edilmiş ölçekler yardımıyla analiz edilmiştir. Öğrenme olgusu; Sujan, Weitz ve Kumar (1994) tarafından geliştirilen öğrenme ölçeğinden, performans boyutu; Sigler ve Pearson'un (2000), Kirkman ve Rosen'dan (1999) aldığı ifadeler ile Behrman ve Perreault'ın (1982) ölçek ifadeleri destek alınarak hazırlanmıştır. Yaratıcılık bileşeni ise; Balay'ın (2010) yurt içi ve yurt dışı literatürü inceleyerek hazırladığı örgütsel yaratıcılık anketinden maddeler içermektedir. Tüm bu değişkenlerin ölçeklerine dair ilk maddeleri örnek olarak Tablo 1'de görmek mümkündür. Yapısal eşitlik modeli, ölçme araçlarını daha önce kullanan araştırmacıların buldukları güvenilirlik katsayıları açısından, aynı ölçme araçlarını kullanan diğer araştırmacıların da aynı sonuçları bulacağını garantilemez. Dolayısıyla, her bir araştırmanın kendi data setinden hesaplanan güvenilirlik katsayıları rapor edilmelidir (Çepni, 2010). Bulgular bölümünde bu katsayılar ve uyum iyiliği değerleri tablolar ve şekillerle desteklenerek verilmiştir.

Tablo 1. Araştırma Modelinin Değişkenleri ve Örnek Ölçek ifadeleri

\begin{tabular}{ll}
\hline \hline Değişkenin Adı & Örnek Ölçek ifadesi \\
\hline Süreç Kontrolü & $\begin{array}{l}\text { A1: Doğrudan bağlı olduğum yöneticim, belirli prosedürleri izleme } \\
\text { düzeyimi kontrol eder. }\end{array}$ \\
& B1: İşim için belirli performans hedefleri saptanmıştır. \\
Şısłı Kontrolü & C1: Birimim, çalışanlar arasında işbirliğini teşvik etmektedir. \\
Kişisel Kontrol & D1: Hayatımdaki temel tatminler işimden kaynaklanmaktadır. \\
Yaratıcılık & E1: Yeni yaşantı ve deneyimleri merak ederek, çeşitli konularla ya- \\
& kından ilgilenirim. \\
Performans & F1: Görevlerimi tam zamanında tamamlarım. \\
Öğrenme & G1: İyi bir eleman olmanın önemli bir parçası işle ilgili becerilerini sü- \\
& rekli olarak geliştirmektir. \\
\hline
\end{tabular}

Örneklem konusunda uygun büyüklük açısından bakıldığında Gorsuch (1983), yapısal eşitlik modeli için kullanılan ölçme aracında yer alan her bir madde sayısı için en az beş kişiden anket toplanması gerektiğini ifade etmiştir. Floyd ve Widaman (1995) örneklem büyüklügünün faktör analizi için madde başına 4:1 veya 5:1 oranını yeterli görmektedir Ankette yer alan toplam madde sayısı 40 olduğu için 200 ve üstü bu şartlarda yeterlidir. Araştırmanın örneklem büyüklüğü 500 kişinin çalıştığı bir firmada, araştırmaya destek vermeyi kabul eden 275 katılımcıdan oluşmaktadır. 275 kişilik örneklem büyüklüğü analiz düzeyinde yeterli bir rakamdır.

Bu araştırma kapsamında sınırlıık olarak görülen konu ise havacılık sanayini temsilen tek bir şirketle çalışılmasıdır. Kurumların özellikle güvenlik gerekçesiyle ulaşııılığının düşük olması ve örnek- 


\section{Güzin KIYIK KICIR}

lem grubunun homojenliğini bozmamak adına farklı şirketler araştırmaya dahil edilmemiş, analiz düzeyinde yeterli görülen katılımcı ile çalışma tamamlanmıştır. Dolayısıyla örneklem ve analiz sonuçlarının genellenebilirliği konusunda sınırlılık söz konusudur.

\section{Bulgular}

Demografik açıdan bakıldığında katılımcıların \%90,2'sini erkekler, yüzde 9,8'ini ise kadın çalışanlar oluşturmaktadır. Yaş dağılımına gelindiğinde ağırlığın 26 ile 35 yaş arasında toplandığı ve bu aralığın tüm grubun \% 64,14'ünü oluşturduğu görülmektedir.

Tablo 2. Demografik Dağlımlar

\begin{tabular}{|c|c|c|c|c|c|}
\hline Cinsiyet & Kişi Sayısı & Yüzde & Yaş & Kişi Sayısı & Yüzde \\
\hline \multirow{2}{*}{ Kadın } & \multirow{2}{*}{27} & \multirow{2}{*}{9,8} & 25 Yaş ve & & \\
\hline & & & Altı & 40 & 14,7 \\
\hline Erkek & 248 & 90,2 & 26-30 Yaş & 109 & 39,9 \\
\hline Görev & Kiși Sayısı & $\underline{\text { Yüzde }}$ & 31-35 Yaş & 67 & 24,5 \\
\hline Beyaz Yaka & 96 & 35,6 & 36-40 Yaş & 36 & 13,2 \\
\hline \multirow{2}{*}{ Mavi Yaka } & \multirow{2}{*}{174} & \multirow{2}{*}{64,4} & 41 Yaş ve & & \\
\hline & & & Üzeri & 21 & 7,7 \\
\hline Eğitim Durumu & Kişi Sayısı & Yüzde & Çalışma Yılı & Kişi Sayısı & Yüzde \\
\hline Ortaöğretim & 8 & 2,9 & $0-1$ YII & 61 & 22,3 \\
\hline Lise & 141 & 51,3 & 1-5 Yll & 125 & 45,6 \\
\hline Üniversite & 111 & 40,4 & 5-10 YII & 62 & 22,6 \\
\hline \multirow[t]{2}{*}{ Lisansüstü } & 15 & 5,5 & 10-20 YII & 25 & 9,1 \\
\hline & & & $\begin{array}{l}20 \text { Yıl ve } \\
\text { Üzeri }\end{array}$ & 1 & 0,4 \\
\hline
\end{tabular}

Katılımcıların eğitim düzeyi açısından en düşük yüzdeler orta eğitim $(\% 2,9)$ ve lisansüstü eğitim alan kişilerde $(\% 5,5)$ görülürken, ağırlığın lise $(\% 51,3)$ ve üniversite mezunlarında $(\% 40,4)$ olduğu tespit edilmiştir. Örnekleme konu olan havacılık sanayinde faaliyet gösteren kurum çalışanlarının \% 64'4 ü mavi yaka, \%35'i ise beyaz yakalıdır. Son olarak işyerindeki çalışma yıllarına bakıldığında yoğunluğun \%45,6'ık oranla 1-5 yıllık iş tecrübesine sahip çalışanlarda olduğu görülmektedir. 0-1 yıllık $(\% 22,3)$ ve 5-10 yıllık $(\% 22,6)$ çalışanların ise benzer oranlara sahip olduğu dikkati çekmektedir. Araştırmaya katılan çalışanlara ait demografik bilgilerin tamamını Tablo2'de görmek mümkündür. 
Tablo 3. Resmi Kontrol Bileşenleri Ölçeğinde Doğrulayıcı Faktör Analizi (DFA) Uyum İyiliği Değerleri

\begin{tabular}{|c|c|c|c|c|}
\hline $\begin{array}{l}\text { Uyum Öl- } \\
\text { çüsü }\end{array}$ & İyi Uyum & Kabul Edilebilir Uyum & Değeri & Uyum Durumu \\
\hline$\chi^{2} / S d$ & $0<\chi^{2} / S d<2$ & $2<\chi^{2} / S d<5$ & $52,422 / 24=2,184$ & $\begin{array}{c}\text { Kabul Edilebilir } \\
\text { Uyum }\end{array}$ \\
\hline RMSEA & $\begin{array}{c}0,00< \\
\text { RMSEA }<0,05\end{array}$ & $0,05<$ RMSEA<0,08 & 0,066 & $\begin{array}{c}\text { Kabul Edilebilir } \\
\text { Uyum }\end{array}$ \\
\hline $\mathrm{CFI}$ & $0,97<\mathrm{CFI}<1$ & $0,95<\mathrm{CFI}<0,97$ & 0,978 & İyi Uyum \\
\hline GFI & $0,90<\mathrm{GFI}<1$ & $0,85<\mathrm{GFI}<0,89$ & 0,961 & İyi Uyum \\
\hline AGFI & $0,90<A G F I<1$ & $0,85<A G F I<0,89$ & 0,926 & İyi Uyum \\
\hline
\end{tabular}

Doğrulayıcı Faktör Analizi (DFA) sonucunda Süreç Kontrolü boyutu altında yer alan "Performans hedeflerime nasıl ulaştığıma ilişkin geri bildirim alııım." ifadeli A4 sorusunun Çıktı Kontrolü boyutundaki diğer sorularla güçlü ilişkisinin olduğu görülmüş ve kapsam geçerliliği örtüşen A4 sorusu Çıktı Kontrolü boyutunun altında değerlendirilmiştir. Analizler sonucunda uyum iyiliği değerleri tabloda verilmiştir. Uyum iyiliği değerleri incelendiğinde oluşturulan model doğrulanmış, ölçeğin geçerliliği sağlanmıştır.

Şekil 1. Resmi Kontrol Bileşenlerinin Alt Boyutlarına Iliş̧in Doğrulayıcı Faktör Analizi

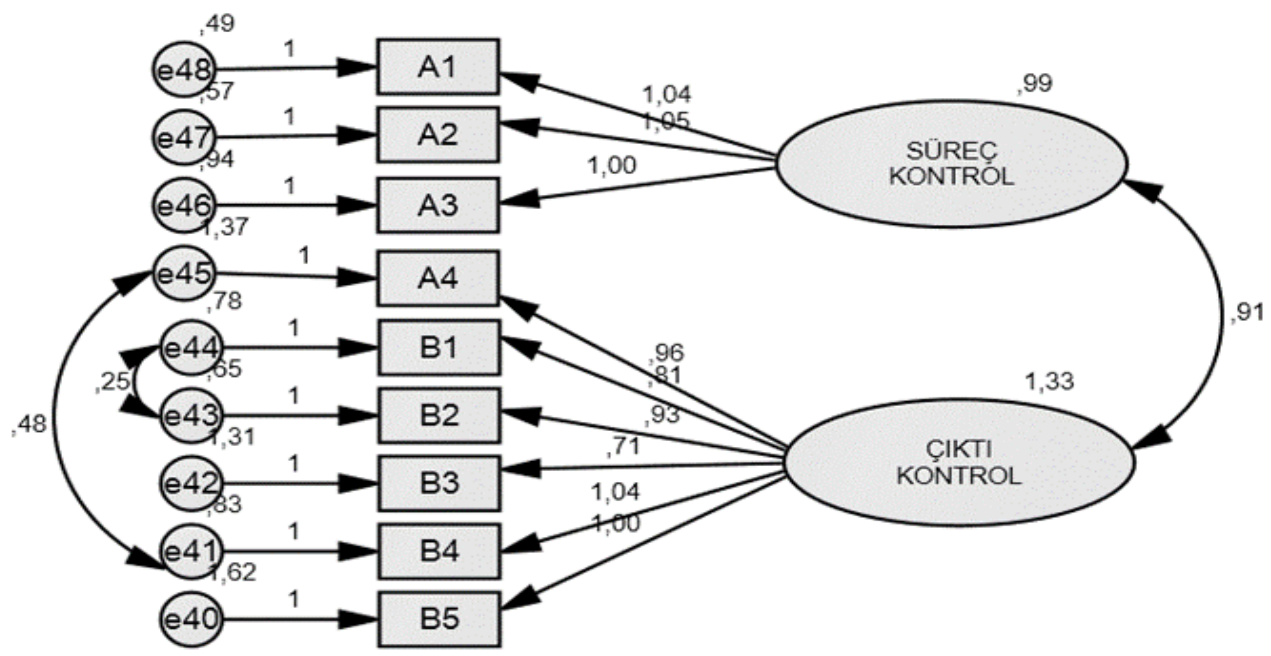


Güzin KIYIK KICIR

Tablo 4. Gayri Resmi Kontrol Bileşenleri Ölçeğinde Doğrulayıcı Faktör Analizi Uyum İyiliği Değerleri

\begin{tabular}{ccccc}
\hline $\begin{array}{c}\text { Uyum Öl- } \\
\text { çüsü }\end{array}$ & İyi Uyum & Kabul Edilebilir Uyum & Değeri & Uyum Durumu \\
\hline$\chi^{2} / \mathrm{Sd}$ & $0<\chi^{2} / \mathrm{Sd}<2$ & $2<\chi^{2} / \mathrm{Sd}<5$ & $57,598 / 25=2,304$ & $\begin{array}{c}\text { Kabul Edilebilir } \\
\text { Uyum }\end{array}$ \\
RMSEA & $0,00<$ & $0,05<\mathrm{RMSEA}<0,08$ & 0,069 & $\begin{array}{c}\text { Kabul Edilebilir } \\
\text { Uyum }\end{array}$ \\
CFI & $0,97<\mathrm{CFI}<1$ & $0,95<\mathrm{CFI}<0,97$ & 0,965 & $\begin{array}{c}\text { İyi Uyum } \\
\text { GFI }\end{array}$ \\
RMSEA $<0,05$ & $0,90<\mathrm{GFI}<1$ & $0,85<\mathrm{GFI}<0,89$ & 0,957 & İyi Uyum \\
AGFI & $0,90<\mathrm{AGFI}<1$ & $0,85<\mathrm{AGFI}<0,89$ & 0,922 & İyi Uyum \\
\hline
\end{tabular}

Doğrulayıcı Faktör Analizi (DFA) sonucunda elde edilen uyum iyiliği değerleri tabloda verilmiştir. Uyum iyiliği değerleri incelendiğinde oluşturulan model doğrulanmış, ölçeğin geçerliliği sağlanmıştır.

Şekil 2. Gayri Resmi Kontrol Bileşenlerinin Alt Boyutlarına Illişkin Doğrulayıcı Faktör Analizi

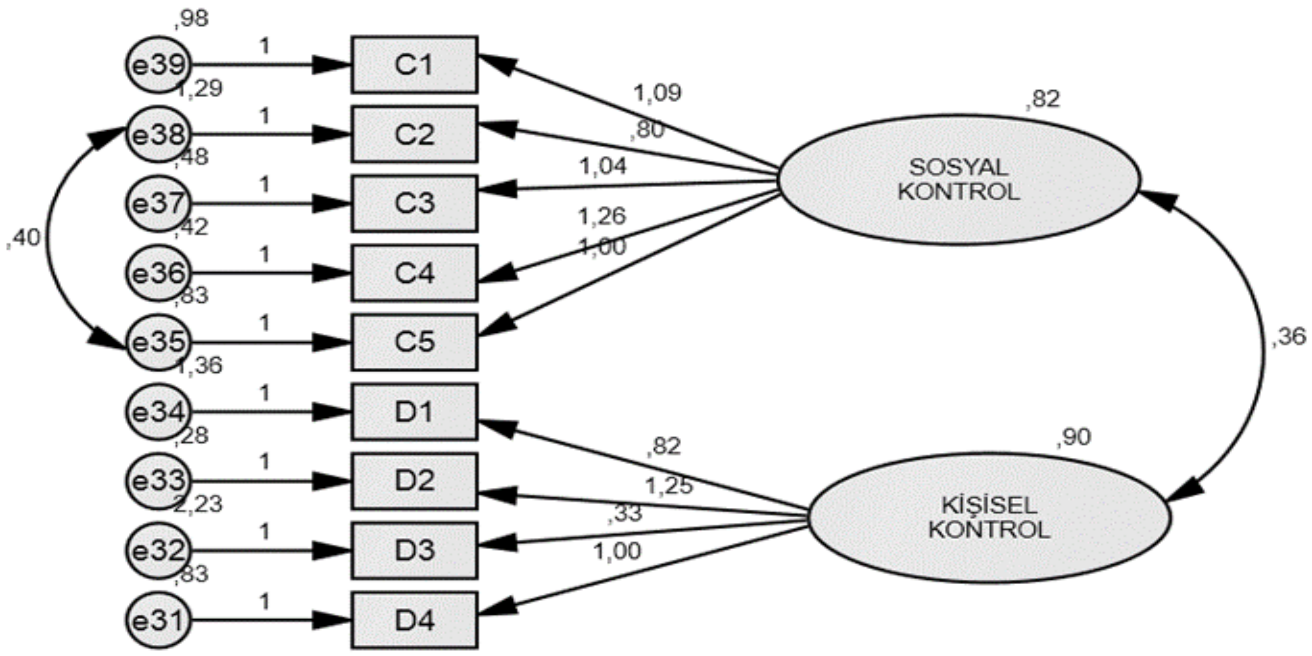


Eskişehir Osmangazi Üniversitesi Sosyal Bilimler Dergisi

Tablo 5. Öğrenme Ölçeğinde Doğrulayıcı Faktör Analizi (DFA) İ̧in Uyum Iyiliği Değerleri

\begin{tabular}{|c|c|c|c|c|}
\hline Uyum Ölçüsü & İyi Uyum & $\begin{array}{l}\text { Kabul Edilebilir } \\
\text { Uyum }\end{array}$ & Değeri & Uyum Durumu \\
\hline$\chi^{2} / S d$ & $0<\chi^{2} / S d<2$ & $2<\chi^{2} / S d<5$ & $45,979 / 18=2,554$ & $\begin{array}{c}\text { Kabul Edilebilir } \\
\text { Uyum }\end{array}$ \\
\hline RMSEA & $\begin{array}{c}0,00< \\
\text { RMSEA }<0,05\end{array}$ & $0,05<$ RMSEA $<0,08$ & 0,075 & $\begin{array}{c}\text { Kabul Edilebilir } \\
\text { Uyum }\end{array}$ \\
\hline $\mathrm{CFI}$ & $0,97<\mathrm{CFI}<1$ & $0,95<\mathrm{CFI}<0,97$ & 0,951 & İyi Uyum \\
\hline GFI & $0,90<\mathrm{GF} \mid<1$ & $0,85<\mathrm{GF} \mid<0,89$ & 0,959 & İyi Uyum \\
\hline AGFI & $0,90<A G F I<1$ & $0,85<A G F \mid<0,89$ & 0,918 & İyi Uyum \\
\hline
\end{tabular}

Doğrulayııı Faktör Analizi (DFA) sonucunda elde edilen uyum iyiliği değerleri tabloda verilmiştir. Uyum iyiliği değerleri incelendiğinde oluşturulan model doğrulanmış, ölçeğin geçerliliği sağlanmıştır.

Şekil 3. Öğrenmenin Alt Boyutlarına Iliş̧in Doğrulayıcı Faktör Analizi

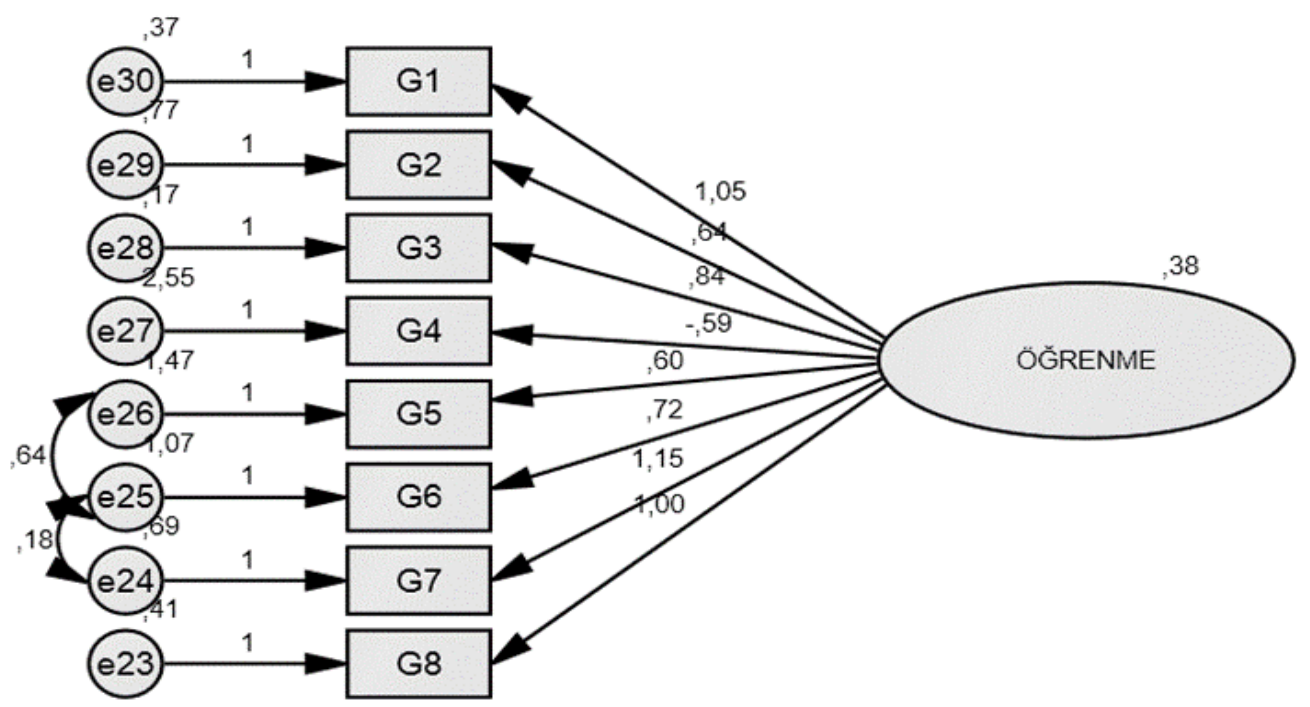


Güzin KIYIK KICIR

Tablo 6. Yaratıcılık Ölçeğinde Doğrulayıcı Faktör Analizi (DFA) İçin Uyum İyiliği Değerleri

\begin{tabular}{|c|c|c|c|c|}
\hline $\begin{array}{c}\text { Uyum Öl- } \\
\text { çüsü }\end{array}$ & Iyi Uyum & Kabul Edilebilir Uyum & Değeri & Uyum Durumu \\
\hline$\chi^{2} / S d$ & $0<\chi^{2} / S d<2$ & $2<\chi^{2} / S d<5$ & $35,003 / 18=1,945$ & İyi Uyum \\
\hline RMSEA & $0,00<$ RMSEA $<0,05$ & $0,05<$ RMSEA $<0,08$ & 0,059 & $\begin{array}{c}\text { Kabul Edilebilir } \\
\text { Uyum }\end{array}$ \\
\hline $\mathrm{CFI}$ & $0,97<\mathrm{CFI}<1$ & $0,95<C F I<0,97$ & 0,976 & İyi Uyum \\
\hline GFI & $0,90<\mathrm{GFI}<1$ & $0,85<\mathrm{GFI}<0,89$ & 0,970 & İyi Uyum \\
\hline AGFI & $0,90<A G F I<1$ & $0,85<A G F I<0,89$ & 0,940 & İyi Uyum \\
\hline
\end{tabular}

Doğrulayıcı Faktör Analizi (DFA) sonucunda elde edilen uyum iyiliği değerleri tabloda verilmiştir. Uyum iyiliği değerleri incelendiğinde oluşturulan model doğrulanmış, ölçeğin geçerliliği sağlanmıştır

Şekil 4. Yaratıcılığın Alt Boyutlarına İlişkin Doğrulayıcı Faktör Analizi

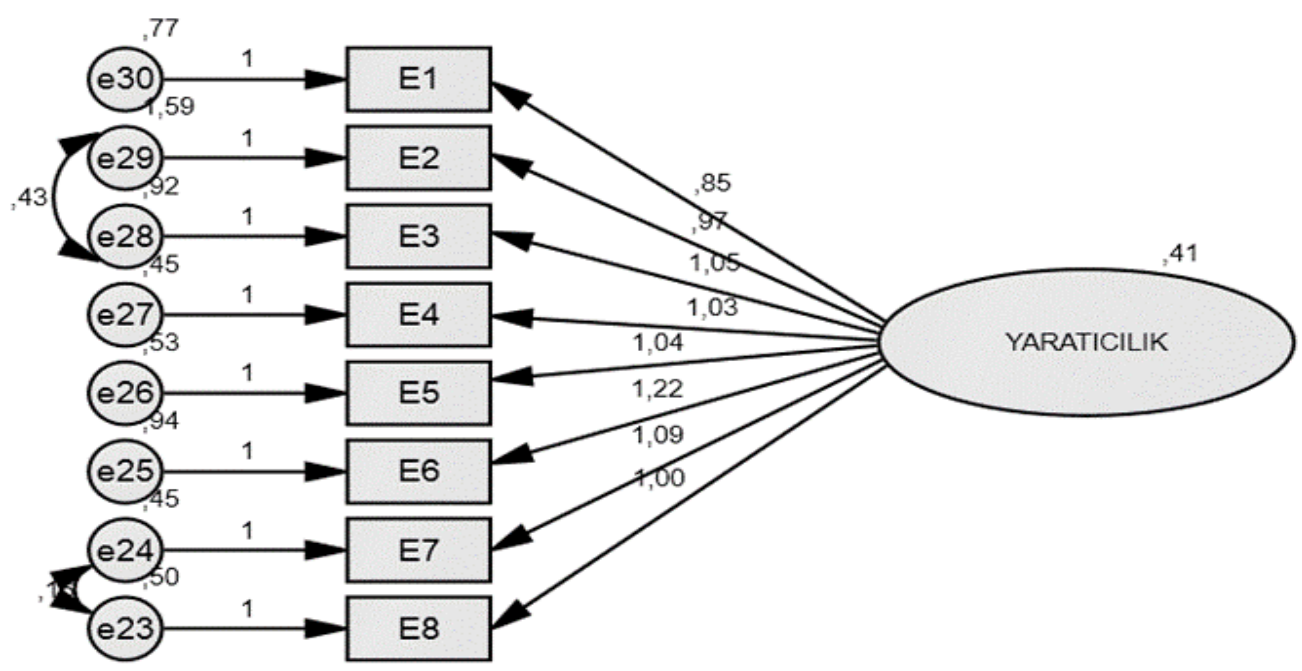


Tablo 7. Performans Ölçeğinde Doğrulayıcı Faktör Analizi (DFA) İçin Uyum İyiliği Değerleri

\begin{tabular}{|c|c|c|c|c|}
\hline $\begin{array}{c}\text { Uyum Öl- } \\
\text { çüsü }\end{array}$ & Iyi Uyum & Kabul Edilebilir Uyum & Değeri & Uyum Durumu \\
\hline$\chi^{2} / S d$ & $0<\chi^{2} / S d<2$ & $2<\chi^{2} / S d<5$ & $11,496 / 6=1,916$ & İyi Uyum \\
\hline RMSEA & $0,00<$ RMSEA $<0,05$ & $0,05<$ RMSEA $<0,08$ & 0,058 & $\begin{array}{c}\text { Kabul Edilebilir } \\
\text { Uyum }\end{array}$ \\
\hline CFI & $0,97<\mathrm{CFI}<1$ & $0,95<\mathrm{CFI}<0,97$ & 0,991 & İyi Uyum \\
\hline GFI & $0,90<\mathrm{GFI}<1$ & $0,85<\mathrm{GFI}<0,89$ & 0,987 & İyi Uyum \\
\hline AGFI & $0,90<A G F I<1$ & $0,85<A G F I<0,89$ & 0,953 & İyi Uyum \\
\hline
\end{tabular}

Doğrulayıcı Faktör Analizi (DFA) sonucunda elde edilen uyum iyiliği değerleri tabloda verilmiştir. Uyum iyiliği değerleri incelendiğinde oluşturulan model doğrulanmış, ölçeğin geçerliliği sağlanmıştır.

Şekil 5. Performansın Alt Boyutlarına İlişkin Doğrulayıcı Faktör Analizi

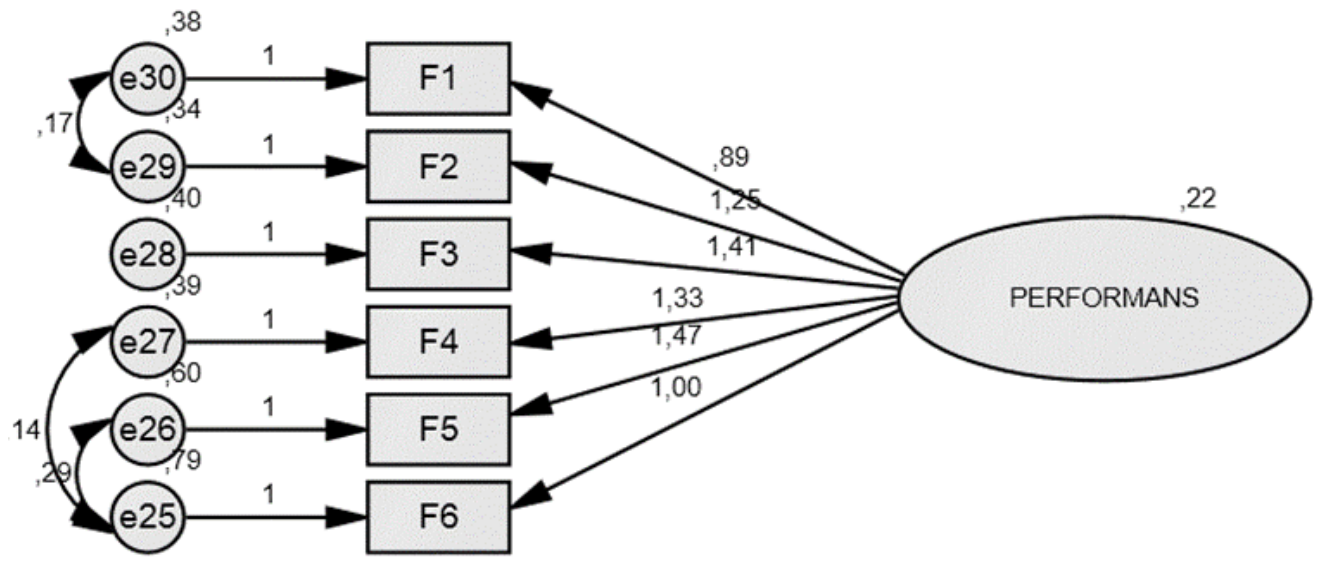

Tablo 8. Araştırma Modeli İçin Uyum İyiliği Değerleri

\begin{tabular}{ccccc}
\hline $\begin{array}{c}\text { Uyum Öl- } \\
\text { çüsü }\end{array}$ & iyi Uyum & Kabul Edilebilir Uyum & Değeri & Uyum Durumu \\
\hline$\chi^{2} / \mathrm{Sd}$ & $0<\chi^{2} / \mathrm{Sd}<2$ & $2<\chi^{2} / \mathrm{Sd}<5$ & $2,352 / 2=1,176$ & İyi Uyum \\
$\mathrm{RMSEA}$ & $0,00<\mathrm{RMSEA}<0,05$ & $0,05<\mathrm{RMSEA}<0,08$ & 0,025 & İyi Uyum \\
CFI & $0,97<\mathrm{CFI}<1$ & $0,95<\mathrm{CFI}<0,97$ & 1,000 & İyi Uyum \\
GFI & $0,90<\mathrm{GFI}<1$ & $0,85<\mathrm{GFI}<0,89$ & 0,998 & İyi Uyum \\
AGFI & $0,90<\mathrm{AGFI}<1$ & $0,85<\mathrm{AGFI}<0,89$ & 0,966 & İyi Uyum \\
\hline
\end{tabular}




\section{Güzin KIYIK KICIR}

Analizler sonucunda elde edilen uyum iyiliği değerleri tabloda verilmiştir. Uyum iyiliği değerleri incelendiğinde oluşturulan model doğrulanmıştır.

Şekil 6. Araştırma Modelinin Path (Yol) Diyagramı

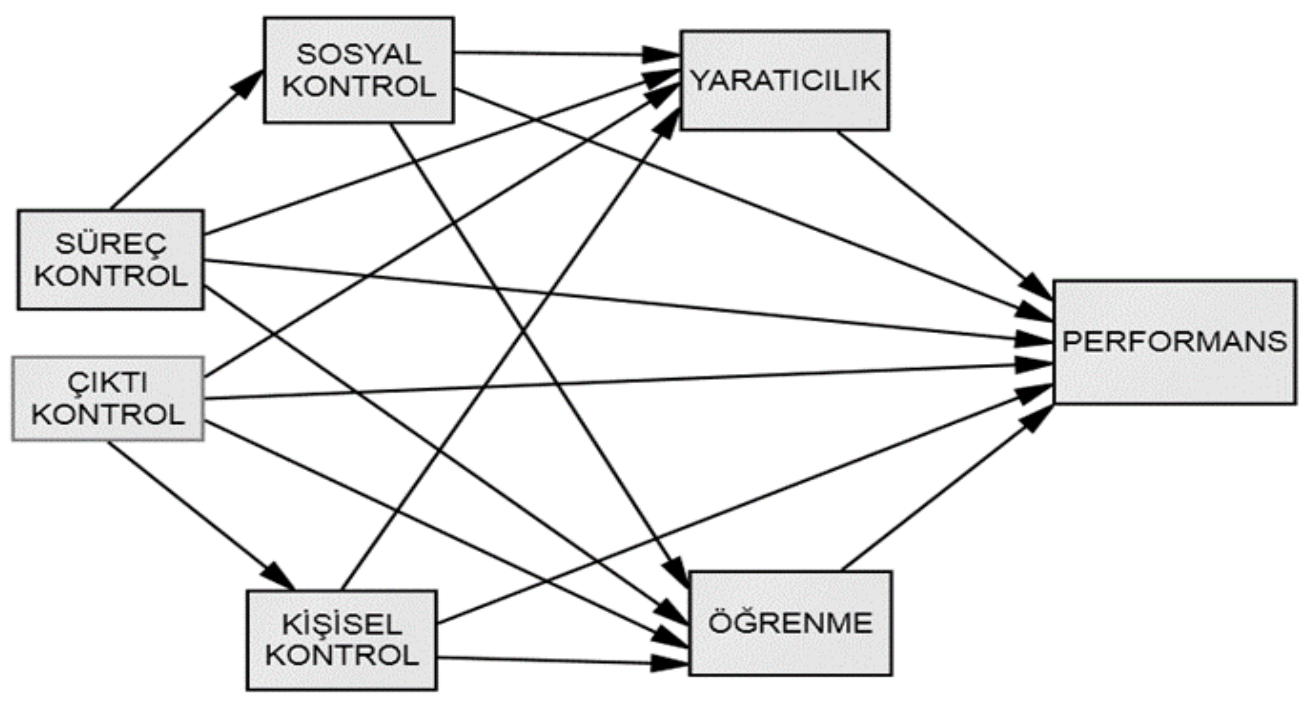

Tablo 9. Model Yol Katsayıları

\begin{tabular}{lcllll}
\hline \hline & & & Beta & $t$ & $p$ \\
\hline Süreç Kontrol & $\rightarrow$ & Sosyal Kontrol & 0,573 & 13,575 & $0,000^{* *}$ \\
Çıktı Kontrol & $\rightarrow$ & Kişisel Kontrol & 0,321 & 7,121 & $0,000^{* *}$ \\
Sosyal Kontrol & $\rightarrow$ & Yaratıılık & 0,054 & 1,039 & 0,299 \\
Kişisel Kontrol & $\rightarrow$ & Yaratıılık & 0,207 & 4,984 & $0,000^{* *}$ \\
Süreç Kontrol & $\rightarrow$ & Yaratıııık & 0,042 & 0,549 & 0,583 \\
Çıktı Kontrol & $\rightarrow$ & Yaratıııı & 0,015 & 0,245 & 0,806 \\
Sosyal Kontrol & $\rightarrow$ & Öğrenme & 0,031 & 0,640 & 0,522 \\
Kişisel Kontrol & $\rightarrow$ & Öğrenme & 0,245 & 6,215 & $0,000^{* *}$ \\
Süreç Kontrol & $\rightarrow$ & Öğrenme & 0,148 & 2,016 & $0,044^{*}$ \\
Çıktı Kontrol & $\rightarrow$ & Öğrenme & $-0,123$ & $-2,066$ & $0,039^{*}$ \\
\hline
\end{tabular}




\begin{tabular}{llllll}
\hline Sosyal Kontrol & $\rightarrow$ & Performans & 0,001 & 0,040 & 0,968 \\
Kişisel Kontrol & $\rightarrow$ & Performans & 0,012 & 0,419 & 0,675 \\
Süreç Kontrol & $\rightarrow$ & Performans & 0,031 & 0,652 & 0,515 \\
Çıktı Kontrol & $\rightarrow$ & Performans & $-0,035$ & $-0,881$ & 0,378 \\
Öğrenme & $\rightarrow$ & Performans & 0,168 & 3,696 & $0,000^{* *}$ \\
Yaratıcılık & $\rightarrow$ & Performans & 0,346 & 8,028 & $0,000^{* *}$ \\
\hline
\end{tabular}

Araştırma modeline ilişkin yol katsayıları incelendiğinde ilk olarak sosyal kontrolün çalışanların öğrenme davranışı, yaratıcılığı ve performansı üzerinde etkili olmadığı görülmüştür. Faktörler arasında anlamlı bir ilişki bulunmaması nedeniyle H1 ("H1: Sosyal kontrol, çalışanların öğrenme davranışını pozitif yönde etkiler."), H2 ("Sosyal kontrol, çalışanların yaratııılı̆ı̆ı pozitif yönde etkiler."), H3 ("Sosyal kontrol, çalışanların performansını pozitif yönde etkiler.") hipotezleri doğrulanmamıştır.

Kişisel kontrolün çalışanların öğrenme davranışı ve yaratıcılıkları üzerinde pozitif bir etkiye sahip olduğu ortaya çıkmıştır. Bu bağlamda çalışanların kişisel kontrol düzeyleri bir birim arttıkça, öğrenme düzeylerinin 0.245 birim artarken, yaratıcılıklarının 0.207 oranında arttığı görülmektedir. Dolayısıyla H4 ("H4: Kişisel kontrol, çalışanların öğrenme davranışını pozitif yönde etkiler.") ve H5 ("H5: Kişisel kontrol, çalışanların yaratıcılığını pozitif yönde etkiler.") hipotezleri doğrulanmıştır. Bununla beraber kişisel kontrol ve çalışan performansı arasında anlamlı bir ilişki bulunamadığı için H6 ("H6: Kişisel kontrol, çalışanların performansını pozitif yönde etkiler.") hipotezi doğrulanmamıştır.

Araştırmanın diğer bir boyutu olan süreç kontrolüne gelindiğinde; süreç kontrolü ile çalışanların öğrenme davranışı arasında pozitif bir ilişki olduğu, yaratıcılık ve performans boyutlarıyla ise aralarında anlamlı bir ilişki olmadığı ortaya çıkmıştır. Bu bağlamda H7 ("Süreç kontrolü, çalışanların öğrenme davranışını negatif yönde etkiler.") hipotezi aradaki ilişkinin yönü pozitif olmasından dolayı reddedilmiş̧ir. H8 ("Süreç kontrolü, çalışanların yaratıcılığını negatif yönde etkiler.") ve H9 ("Süreç kontrolü, çalışanların performansını pozitif yönde etkiler.") hipotezleri faktörler arasında anlamlı bir ilişki bulunamadığı için kabul edilmemiştir.

Çıktı kontrolü ile çalışanların öğrenme davranışı arasında negatif yönlü bir ilişki bulunmuştur. Buna göre kontrol düzeyindeki bir birimlik artış, çalışanların öğrenme davranışlarında 0.123 birimlik bir azalışa neden olmaktadır. Dolayısıyla H10 ("Çıktı kontrolü, çalışanların öğrenme davranışını negatif yönde etkiler.") hipotezi doğrulanmıştır. Bununla birlikte H11 (“Çıktı kontrolü, çalışanların yaratıcılığını negatif yönde etkiler.") ve H12 ("Çıktı kontrolü, çalışanların performansını pozitif yönde etkiler.") hipotezleri için tespit edilen değerler arasında anlamlı bir ilişki bulunamadığı için bu iki hipotez reddedilmektedir.

Sosyal kontrolün yaratıclık ve performans üzerindeki etkisini sorgulayan H13 ("Sosyal kontrol, çalışanların performansını öğrenme davranışı üzerinden etkiler.") ve H14 ("Sosyal kontrol, çalışanların performansını yaratıılık üzerinden etkiler.") hipotezleri için araştırma modelinde çıkan sonuçlar 


\section{Güzin KIYIK KICIR}

incelendiğinde bu boyutlar arasında da anlamlı bir ilişki bulunamamıştır. Dolayısıyla H13 ve H14'te araştırma kapsamında kabul edilmeyen hipotezlerdendir.

Kişisel kontrol ile performans arasındaki ilişkide, öğrenme ve yaratıcılık boyutlarının aracılık görevini irdeleyen $\mathrm{H} 15$ ("Kişisel kontrol, çalışanların performansını öğrenme davranışı üzerinden etkiler.") ve H16 ("Kişisel kontrol, çalışanların performansını yaratııılık üzerinden etkiler.") hipotezlerine gelindiğinde; boyutlar arasında tespit edilen anlamlı değerler nedeniyle $\mathrm{H} 15$ ve H16'nın doğrulandığı ifade edilebilir. Buna göre; kişisel kontrol öğrenmeyi ve öğrenmede performansı etkilemektedir. Ayrıca kişisel kontrol yaratıcılığı ve yaratıcılıkta performansı etkilemektedir.

Süreç kontrolü ve performans arasındaki ilişkiye, öğrenme ve yaratıclık boyutlarının aracılık yapıp yapmadığını sorgulayan H17 (“Süreç kontrolü, çalışanların performansını öğrenme davranışı üzerinden etkiler.") ve H18 ("Süreç kontrolü, çalışanların performansını yaratıclık üzerinden etkiler.") hipotezlerinden ilki süreç kontrolünün öğrenmeyi ve öğrenmenin de performansı etkilemesi nedeniyle kabul edilmiştir. $\mathrm{H} 18$ ise; süreç kontrolü yaratıcılığı etkilemediği ve arada anlamlı bir ilişki olmadığı için reddedilmiştir.

Çıktı kontrolü ile çalışan performansı arasındaki ilişkinin öğrenme ve yaratıcılık boyutları aracılığıyla etkileşimini inceleyen $\mathrm{H} 19$ ("Çıktı kontrolü, çalışanların performansını öğrenme davranışı üzerinden etkiler.") ve H2O ("Çıktı kontrolü, çalışanların performansını yaratıcılık üzerinden etkiler.") hipotezlerine gelindiğinde, $\mathrm{H} 19$ 'un sözü edilen boyutlar arasındaki anlamlı ilişkilerden dolayı doğrulandığı görülmüştür. Bununla birlikte H2O, çıktı kontrolü ile yaratıcılık arasında bir ilişki tespit edilememesi nedeniyle kabul edilmemiştir.

Araştırma modeli ve yol katsayıları incelendiğinde süreç kontrolünün, sosyal kontrolü pozitif şekilde etkilediği görülmüştür. Bu bağlamda çalışanların süreç kontrol düzeyleri bir birim arttıkça, sosyal kontrol düzeyleri 0,573 birim artmaktadır. Çıktı kontrolü ise kişisel kontrolü pozitif şekilde etkilemektedir. Çalışanların çıktı kontrol düzeyleri bir birim arttıkça, kişisel kontrol düzeyleri 0,321 birim artmaktadır. Kişisel kontrol boyutuna bakıldığında, yaratıcılı̆ı pozitif şekilde etkilediği ortaya çıkmıştır. Çalışanların kişisel kontrol düzeyleri bir birim arttıkça, yaratıcılık düzeyleri de 0,207 birim artmaktadır. Kişisel kontrol, öğrenmeyi ise pozitif şekilde etkilemektedir. Çalışanların kişisel kontrol düzeyleri bir birim arttıkça, öğrenme düzeyleri 0,245 birim artmaktadır. Araştırmanın diğer bir değişkeni olan süreç kontrolü, öğrenmeyi pozitif şekilde etkilemektedir. Çalışanların süreç kontrol düzeyleri bir birim arttıkça, öğrenme düzeyleri 0,148 birim artmaktadır. Çıktı kontrolüne gelindiğinde, öğrenme davranışını negatif şekilde etkilediği tespit edilmiştir. Çalışanların çıktı kontrol düzeyleri bir birim arttıkça, öğrenme düzeyleri 0,123 birim azalmaktadır. Öğrenme ve performansı arasındaki ilişki pozitiftir. Buna göre çalışanların öğrenme düzeyleri bir birim arttıkça, performans düzeyleri de 0,168 birim artmaktadır. Son olarak yaratıcılık ve performans etkileşimine bakıldığında aradaki ilişkinin pozitif olduğu görülmüştür. Çalışanların yaratıcılık düzeyleri bir birim arttığında, performansları 0,346 birim artmaktadır.

\section{Değerlendirme}


Araştırma kapsamında faktörler arasında tespit edilen en güçlü ilişki iki kontrol türü olan süreç kontrolü ile sosyal kontrol arasındadır. Bulgulara göre işletmelerdeki süreçlere dair tüm kontrol faaliyetleri, insan ilişkileriyle şekillenen sosyal kontrolü pozitif şekilde etkilemektedir. Daha önce yapılan araştırmalarda özellikle süreç kontrolü ile uyumlu sosyal kontrol algılarının gelişmesini sağlayacak örgütsel koşulların sağlanması durumunda, kontrol sistemi ile elde edilmek istenen davranış çıktılarının elde edilmesinin önemli ölçüde kolaylaşacağını ortaya koymuştur (Yücel, Eren, 2010). Araştırmamızda ayrıca yaratıcııı ve çalışanların performansları arasında güçlü bir ilişki tespit edilmiştir. Bu sonuç; örgütsel yaratıcılığın desteklendiği bir örgüt ortamıyla birlikte ortaya çıkan iş gören performansının diğer örgütlerden farklı olduğunu kanıtlayan ve yaratıcılığın performansı pozitif yönde etkilediğini savunan Zou ve Shalley'in (2008) yaptıkları araştırmaya da paralellik göstermektedir. Ortaya çıkan ürün ya da hizmete dair kontrolü kapsayan çıktı kontrolü ile kişinin kendisi üzerindeki kişisel kontrolü arasındaki anlamlı ilişki de çalışmada dikkati çeken bir diğer yüksek değerli ilişki olmaktadır. Çıktı kontrolüne dair daha önce yürütülen bir araştırmada (Yücel Eren, 2010) tek başına doğrudan davranış belirleyici olmadığı ancak sosyal kontrolün oluşumunda dolaylı etkiye sahip olduğu görülürken bu çalışmada farklı olarak çıktı kontrolünün kişisel kontrol olgusuyla direkt ilişkisi asıında önemli bir faktör olabilme potansiyeline dair ipucu vermiştir. Çünkü yönetim kontrol sistemleri dikkate alındığında çıktı kontrolleri basit sibernetik sistemler olarak ele alınan bünyesinde çalışanlar için son derece önemli geri besleme ve denetim mekanizmasını barındırmaktadır (Drury, 2000, s.597). Bu bağlamda çıktı kontrolleri denetim ve geri besleme mekanizmalarının işlevini üstlenerek sisteme katkı sağlayan bir rol oynar.

Örgütün iş ve sosyal nitelikli konuları arasında bağlantı kurmanın örgütsel öğrenmeyi yapılandıracağını düşünen Watkins ve Marsick'in (1997) aksine bu araştırmada sosyal kontrol ve öğrenme arasında anlamlı bir ilişki bulunamamıştır. Ayrıca yaratıcılığı organizasyonel performans için zorunlu gören, özellikle sürekli yeni ürün ve hizmet üreterek rekabet eden, yüksek yenilikçi endüstriler için önemli kabul eden Wu vd.'nin (2008) aksine bu çalışmada yaratıcılık ile çalışan performansı arasında da anlamlı ve güçlü bir ilişki tespit edilememiştir. Yine benzer şekilde kişisel kontrolle çalışan performansı arasında, süreç kontrolüyle yaratıclık ve performans boyutları arasında, ayrıca çıktı kontrolüyle yaratııılık ve performans arasında da bir ilişki olmaması dikkati çeken sonuçlar arasındadır.

Öğrenme, yaratıcılık ve çalışan performansı üzerindeki etkileri açısından bakıldığında araştırma kapsamında en büyük ve olumlu etkiye sahip kontrol türü kişisel kontrol olurken, hiçbir faktöre etki edemeyen kontrol türü sosyal kontrol olarak tespit edilmiştir. Kişisel kontrol öğrenme ve yaratıclığı olumlu etkileyebilirken performans açıından bir etki bulunamamıştır. Ancak literatüre bakıldığında Thomas ve Tymon (1994) işlerini nasıl yapmaları gerektiği konusunda söz hakkına sahip işgörenlerin, Liden vd. (1993) ise işleri üzerinde daha fazla kontrole sahip olanların, diğerlerine göre daha yüksek performans gösterdiklerini ifade etmektedir (Spretitzer vd. , 1997: 685). Araştırmamızda kontrol türlerinin hiç biri çalışanların performansı üzerinde etki gösteremezken, yaratıcılığı sadece kişisel kontrol etkilemektedir. Öğrenme üzerinde ise kişisel kontrol ve süreç kontrolü pozitif, çıktı kontrolü negatif etkiye sahiptir. 


\section{Güzin KIYIK KICIR}

Araştırma içerisinde elde edilen bulgulara göre süreç kontrolü ve çıktı kontrolü çalışma kapsamındaki ana boyutlardan sadece öğrenme üzerinde etkilidir. Süreç pozitif, çıktı kontrolü negatif etkiyle öğrenme boyutunu etkilemektedir. Buna göre; bir ürün ya da hizmetin oluşumu sürecindeki kontrol faaliyetleri öğrenmeyi destekleyici olurken, ürün ya da hizmetin ortaya çıkmasından sonraki aşamayı kapsayan çıktı kontrolünün öğrenmeyi negatif etkilediği görülmüştür. Süreç kontrolü açısından alan yazını incelendiğinde gereksiz ve sıkıcı bürokratik yapının işleri zayıflattığını, doğru insan ve doğru yapı olsa dahi projeleri ve öğrenmeyi olumsuz etkilediğini savunan (The 7Ss of Culture, 2006) çalışmalarda vardır. Kurulan sistemler ve yetkilendirme gibi bir sürecin işleyişine dair kontrolü sağlayan unsurların öğrenme üzerinde yapılandırıcı etkiye sahip olduğunu belirten (Watkins and Marsick 1997) görüşlerde mevcuttur.

Araştırma sonuçları incelendiğinde görülmektedir ki kontrol her ne kadar işleyiş, kalite standartları, hata minimizasyonu açısından önemli olsa da klasik ve baskıcı kontrol sistemleri çalışanların performansı, yaratıcılı̆̆ı ve öğrenme davranışlarını desteklememektedir. Destek, özgürlük ve bilgi olmadan, özel kabiliyetlere sahip bireyler dahi başarılı olamaz (Cengiz, Acuner, Baki, 2007). Bu yüzden günümüzde modern ve gelişime yönelik destekleyici kontrol sistemlerine ihtiyaç vardır. Kontrol "ne yapıldı" yerine, "başka ne yapmalı" ve "ne kadar daha iyi yapılabilir" sorularına yanıt aramalıdır. Bu noktada değişim ve yaratıcılığa değer veren bir atmosfer ve destekleyici örgüt iklimi oluşturulmalı, liderlerin dönüştürücü ve postmodern yaklaşımlarla örgütü idare etmesi sağlanmalı, proje ekipleri kurulmalı ve takım çalışmaları desteklenmelidir. Tüm bu faaliyetler, araştırmamızda hiçbir ana boyutu etkileyemediği görülen sosyal kontrol kavramını da aktif ve destekleyici hale getirebilir. Çünkü sosyal formların yapısını oluşturan çalışma şartları, değerler, ilişkiler, otorite bağlantıları bireylerin gelişmesinde önemli rol oynar (Ansburg-Hill, 2003, 1141). Ayrıca Parker (1997) takım üyelerinin görevleri üzerinde daha fazla kontrole ve geniş sorumluluk alanına sahip olduklarında yeniliğin artacağını bulmuştur (Axtell, Holman, Umworth, Wall and Waterson, 2000, 268).

Kişisel kontrol, araştırma içinde umut vadeden sonuçlar veren ve diğer faktörlerle etkileşimi açısından üzerinde durulup, geliştirilmesi gereken bir diğer boyuttur. Bu bağlamda öncelikle katılımcı yönetim uygulamalarının yaygınlaştırıması ve personel güçlendirmeye işletmelerde daha sık yer verilmesi gerekmektedir. Örgüt içi çatışmalar önlenmeli, mevki ve statüye değil düşüncelere değer verildiği hissettirilmeli, işletme içindeki faaliyetlere esneklik kazandırılmalı ve kişinin kendisi üzerindeki kontrolünü destekleyen otonomi kavramı örgütlerde daha çok benimsenmelidir.

Araştırmada çalışan performansını en çok etkileyen değişken yaratıclıktır. Yaratıcılı̆ın performansı olumlu etkilediğini savunan daha önceki araştırmalar gibi bu çalışmada da yaratıcılığın örgütlerde desteklenmesi gerektiği sonucuna ulaşmıştır. Yaratıcılık yalnızca birkaç kişiye verilmiş olağanüstü bir hediye değildir. İnsanın içinde yaşadığı ve çalıştığı sosyal yapının şartlarına göre şekillenen bir unsurdur (Ansburg-Hill, 2003, 1141). Dolayısıyla destekleyici yönetim uygulamalarının verilmesi, danışmanlık ve geri bildirim hizmetlerinin yaygınlaştııılması ve fazla otoritenin azaltılması yaratıcılık üzerinde olumlu etkiler oluşturabilir. Ayrıca Baer vd. (2003) yaratıcılık konusunda çalışanları motive eden gücün dışsal araçlardan (terfi, prim, maaş vb.) çok içsel motivasyon unsurları olduğunu tespit 
etmiştir. Bu nedenle işletmelerin çalışanlarına övgü, tanınma, saygı, takdir gibi içsel motivatörlerle yaklaşması da önemli kabul edilmektedir.

Süreç kontrolü öğrenme ve sosyal kontrol üzerinde etkisi yadsınmaması gereken bir diğer boyuttur. Amabile (1997) insanlara hedeflere ulaşma konusundaki araçlara ilişkin özgürlük verilmesi gerektiğini vurgular. Yani hedeflerin saptanmasındaki özgürlük ve katılımcı yapıdan çok insanlara görevlerini nasıl gerçekleştireceklerine ilişkin sürece dair özgürlük tanınması gerektiğini ifade etmektedir. Süreç kontrolü boyutunun işletmelerde desteklenmesi için katı bürokratik yapılardan uzaklaşımalı ve yerine özellikle yatay ilişkilerin desteklendiği daha esnek ve öğrenmeye daha açık yapılanmalara gidilmelidir. Kapalı ve kötü iletişim kanalları modifiye edilmeli, örgütler monotonluk, hantallık ve formalitelerden kurtarılmalıdır.

\section{Sonuç}

Kontrol olgusunun, işletmelerde çalışanlar üzerinde öğrenme, yaratıcılık ve performans değişkenleri açısından nasıl etkilere sahip olduğunu tekli ve çoklu ilişkilerle sorgulayan bu araştırmada yapısal eşitlik modeli oluşturulup analizler gerçekleştirilmiştir. Sonuçlara bakıldığında hiçbir kontrol türünün performansla arasında anlamlı bir ilişki bulunmaması kontrolün çalışan performansı için gerekli olduğu düşüncesini zayıflatmaktadır. Öğrenmeyi sadece kişisel kontrol ve süreç kontrolü olumlu şekilde desteklerken, çıktı kontrolü negatif etkilemektedir. Çalışanların yaratıcılı̆̆ı boyutuna gelindiğinde tüm kontrol türlerinden sadece kişisel kontrolle aralarında anlamlı ve pozitif bir ilişki bulunmuştur. Dolayısıyla örgütlerde ele aldığımız değişkenlere katkısı anlamında desteklenmesi gereken ilk kontrol türü kişisel kontroldür. Bu bağlamda otonomi, esneklik, personel güçlendirme, katılımcı yönetim uygulamaları yaygınlaştırımalıdır. Sosyal kontrol hiçbir faktöre etki edemese de süreç kontrolü üzerinden en çok potansiyele sahip değişken olarak tespit edilmiştir. Sosyal kontrolü harekete geçirmek amaçlı proje ve takım çalışması uygulamaları, liderlik yaklaşımları, örgüt iklimi ve kültürden faydalanılmalıdır. Klasik baskıcı ve otoriter yaklaşımların yerine vizyoner, destekleyici, örgütü bütün-

cül görebilen esnek kontrol uygulamalarına geçilmelidir. Özellikle öğrenme üzerindeki pozitif etkisi ve sosyal kontrol değişkenine etki gücü açısından süreç kontrolü de önemli bir boyut olarak görülmektedir. Süreçlerde kontrole dair işleyişleri kapsayan bu faktörün geliştirilmesi için bürokratik yapılardan ilişki ve iletişim kanallarının daha açık olduğu esnek yapılanmalara yönelmek gerekliliği, işleyişe dair monotonluk, formalitelerden uzaklaşıp işletmelerin daha çok yaşayan ve öğrenen bir kültüre kaymasının faydalı olacağı düşünülmektedir. 
Güzin KIYIK KICIR

\section{Kaynaklar}

Amabile, T. M., Conti, R., Coon, H., Lazenby, J., Herron, M. (1996). Assessing the Work Environment for Creativity", Academy of Management Journal, Vol: 39, No: 5, pp.1154-1184.

Amabile, T.M. (1997). "Motivating Creativity in Organizations: On Doing What You Love And Loving What You Do", California Management Review, 40 (1), 39-57.

Ansburg, P.I., Hill, K. (2003). "Creative And Analytic Thinkers Differ in Their Use Of Attentional Resources", Personality and Individual Differences, Vol. 34, pp.1141-1152.

Argon, T., Eren A. (2004). İnsan Kaynakları Yönetimi, Nobel Yayınları, Ankara.

Atak M., Atik i. (2007). “Örgütlerde Sürekli Eğitimin Önemi ve Öğrenen Örgüt Oluşturma Sürecine Etkisi Hava Kuvvetleri Komutanlığı Sürekli Eğitim Modeli Örneği”, Havacılık ve Uzay Teknolojileri Dergisi, Ocak, Cilt 3, Sayı 1 ss. 63-70.

Axtell, C.M., Holman, D.J., Unsworth, K.L., Wall, T.D., Waterson, P.E. (2000). "Shopfloor Innovation: Facilitating the Suggestion and Implementation of Ideas", Journal of Occupational \& Organzational Psychology, 73 (3), 265-287.

Baer, M., Oldham, G.R., Cummings, A. (2003). “Rewarding Creativity:When Does It Really Matter?”, The Leadership Quarterly, Vol. 14, pp. 569-586.

Balay R., (2010). The Organizational Creativity Perceptions of Academic Staff, Journal of Faculty of Educational Sciences, Ankara University, Vol: 43, No: 1, 41-78.

Başaran, I.E., (1991). Örgütsel Davranış, Gül Yaınevi, Ankara.

Behrman, D. N. And Perreault, W.D. (1982). Measuring the Performance of Industrial Salespersons, Journal of Business Research, 10,355-370.

Bharadwaj, S., Menon, A. (2000). "Making Innovation Happen in Organizations: Individual Creativity Mechanism, Organizational Creativity Mechanism or Both?”, Journal of Product Innovation Mangement, Vol:17, pp. 424-434.

Bolton, T. (1997). Human Resource Management: An Introduction (Massachusetts: Blackwell Publishers).

Cengiz, E., Acuner T., Baki B. (2007). “Örgütsel Yaratıcılığı Belirleyen Faktörler Arası Yapısal ilişkiler”, Dokuz Eylül Üniversitesi, Sosyal Bilimler Enstitüsü Dergisi, Cilt 9, Sayı: 1.

Çepni, Z. (2010). Yapısal Eşitlik Modellemesi PowerPoint Sunu Notları, Mersin.

Doyrangöl N. (2002). Sermaye Piyasası Aracı Kurumlarında Etkili Bir İç Kontrol Sistemi ve Denetim Fonksiyonu, Lebib Yalkın Matbaası, İstanbul. 
Drury, C. (2000). Management and Cost Accounting. 5th Edition, USA: Thomson Learning.

Elitaş C. (2004). "Kontrol Önlem ve Yordamlarının İç Denetçi Açısından Rolü ve Önemi”, İç Denetim Dergisi, Sayı: 8.

Fayol, H. (1917). Administration Industrielle et Générale, Paris: H.Dunod ET E.Pinat Editeurs.

Floyd, F. J., Widaman, K. F. (1995). "Factor Analysisin the Development and Refinement of Clinical Assessment Instruments" Psychological Assessment,7(3), 286-299.

Gorsuch, R. L. (1983). Factor Analysis (2nd ed.) Hillsdale, NJ: Erlbaum.

Guilford, J.P., (1950). Creativity American Psychologist, 5, 444-454.

Gürkan G. Ç. (2007). “Öğrenen Örgütler: Yüksek Öğrenim Kurumlarının Öğrenen Örgüt Olması”, Yönetim Bilimleri Dergisi-Journal of Administrative Sciences, (5: 2).

Gürsoy, C. T. (1999). Yönetim ve Maliyet Muhasebesi. 2. Baskı, İstanbul: Beta Yayınları.

Hammer, T. H., Vardi, P. (1981). "Locus of Control and Career Self-Management Among NonSupervisory Employees in Industrial Settings," Journal of Vocational Behavior, 18, 13-29.

Hoyle, R.H., Panter, A.T. (1995). Writing about Structural Equation Models. In R. H. Hoyle (Ed.) Structural Equation Modeling: Concepts, Issues and Applications. 158-177. Thousand Oaks, CA: Sage Publications.

Jaworski B. J. (1988). “Toward a Theory of Marketing Control: Environmental Context, Control Types, and Consequences", Journal of Marketing, 52 (July), 23- 39.

Jaworski, B. J., Maclnnis D. J. (1989). Marketing Jobs and Management Controls: Toward a Framework, Journal of Marketing Research, 26 (November), pp. 406- 419.

Kao, J.(1989). Entrepreneurship, Creativity and Organization, Prentice Hall, UK.

Khandekar A., Sharma A. (2006). "Organizational Learning and Performance: Understanding Indian Scenario in Present Global Context", Education + Training, Vol. 48 Iss: 8/9, pp.682 -692.

Kirkman, B.L., Rosen, B. (1999). Beyond Self-Management: Antecedents and Consequences of Team Empowerment, Academy of Management Journal, 42(1), 58-74.

Merchant, K. A. (1988). "Progressing toward a Theory of Marketing Control: A Comment", Journal of Marketing, 52 (July), 40- 44.

Öneren M. (2008). “İ̧̧letmelerde Öğrenen Örgütler Yaklaşımı”, ZKÜ Sosyal Bilimler Dergisi, Cilt 4, Sayı 7, ss. 163-178.

Özgen, H., Kılıç, K., Karademir, B. (2004). “Öğrenmenin Kurumsallaşmasında Toplam Kalite Yönetimi Yaklaşımı”, Çukurova Üniversitesi Sosyal Bilimler Enstitüsü Dergisi, Cilt:13, s:12.

Pugh, D. (1991). Organizational Behaviour. Prentice Hall Interneational (UK) Ltd. 


\section{Güzin KIYIK KICIR}

Schein, E. H. (2004). Organizational Culture and Leadership, San Francisco: Jossey-Bass.

Shalley C., Gilson L., Blum T. (2000). "Matching Creativity Requirements and the Work Environment: Effects On Satisfaction And Intentions to Leave," Academy of Management Journal, 43/2: 215-223.

Sigler, T.H., Pearson, C. M. (2000). Creating an empowering culture: examining the relationship between organizational culture and perceptions of empowerment, Journal of Quality Management, Vol.5, pp.27-52.

Sisaye S. (2005). Management Control Systems and Organizational Development: New Directions for Managing Work Teams. Leadership \& Organization Development Journal, 26 (1), 51-61.

Spreitzer, G. M., Kizilos, M. A., Nason, S. W. (1997). A Dimensional Analysis of the Relationship Between Psychological Empowerment and Effectiveness, Satisfaction, and Strain. Journal of Management, Vol.23, No.5, pp.679-704.

Stoner, J. A. F. (1982). Management, Prentice-Hall INC., NewJersey.

Sujan, H., Weitz B. A., Kumar N. (1994). “Learning Orientation, Working Smart and Effective Selling”, Journal of Marketing, 58 July, 39-52.

Şehitoğlu Y., Zehir C. (2010). "Türk Kamu Kuruluşlarında Çalışan Performansının, Çalışan Sessizliği ve Örgütsel Vatandaşlık Davranışı Bağlamında İncelenmesi”. Amme Idaresi Dergisi,43, 4,87-110.

Tapscott, D. (1998). Dijital Ekonomi, Çev.: Ece Koç, İstanbul: Koç Sistem Yayınları.

The 7 Ss of Culture, (2006). [Çevrimiçi] Elektronik adres: http://www.hq.usace.army.mil/cepa/learning/seven.htm

Tierney, P., Farmer, S. M., Graen, G. B. (1999). An Examination of Leadership and Employee Creativity: The Relevance of Traits and Relationships, Personnel Psychology, 52 (3), 591-620.

Tutar, H., Altınöz, M. (2010). Örgütsel İklimin İşören Performansı Üzerine Etkisi: Ostim İmalat İşletmeleri Çalışanları Üzerine Bir Araştırma, Ankara Üniversitesi Siyasal Bilgiler Fakültesi Dergisi, 65 (2), 196-218.

Uyargil, C. (1994). İşletmelerde Performans Yönetim Sistemi İstanbul: İstanbul Üniversite İşletme Fakültesi Yayını.

Watkins, K. E., Marsick, V. J. (1997). Dimensions of Learning Organization (DLOQ) [survey] Warwick, RI: Partners for the Learning Organization.

Wong, S., Pang, L. (2003a). Motivators to Creativity in the Hotel Industry- Perspectives of Managers and Supervisors, Tourism Management, 24, 551-559. 
Wong , S. C., Ladkin, A., (2008). Exploring the Relationship between Employee Creativity and Job-Related Motivators in the Hong Kong Hotel Industry, International Journal of Hospitality Management, 27, s. 426-437.

Wu, C., McMullen, J. S., Neubert, M. J., Yi, X. (2008). “The Influence of Leader Regulatory Focus On Employee Creativity". Journal Of Business Venturing, 23, 587-602.

Yelboğa, A. (2006). Kişilik Özellikleri ve İş Performansı Arasındaki Ilişkinin Incelenmesi, İ̧̧ Güç Endüstri ilişkileri ve Insan Kaynakları Dergisi, 8 (2),196-211.

Yıldııım, E., (2007). "Bilgi Çağında Yaratıcılığın ve Yaratıcılığı Yönetmenin Önemi", Selçuk Üniversitesi Karaman Iktisadi Idari Bilimler Fakültesi Dergisi, Sayı 12, Yıl 9, Haziran.

Yücel R., Eren S. S. (2010). "Yönetim Kontrolünün Çalışanların Davranış Performansına Etkisi: illaç Şirketlerinde Bir Uygulama", Business and Economics Research Journal, Volume 1., Number 4., pp. 97-118, ISSN: 1309-2448.

Zhou, J., Shalley, C. E. (2008). Expanding the Scope and Impact of Organizational Creativity Research, New York: Lawrence Erlbaum Associates, Taylor \& Francis Group. 